\title{
Conservation status of crocodiles in Ghana and Côte-d'Ivoire, West Africa
}

\author{
Matthew H. Shirley, William Oduro and Hilaire Yaokokore Beibro
}

\begin{abstract}
The population and conservation status of crocodiles throughout West and Central Africa is poorly known and the IUCN Crocodile Specialist Group's highest priority recommendations are country status surveys and examination of potential threats. This study presents survey data and a review of the conservation status of the Nile crocodile Crocodylus niloticus, slender-snouted crocodile Mecistops cataphractus and African dwarf crocodile Osteolaemus tetraspis at 67 sites throughout Ghana and Côte d'Ivoire. No crocodiles were sighted in $31.5 \%$ of surveys but, where encountered, densities averaged 0.90 crocodiles sighted $\mathrm{km}^{-1}$. The most frequently encountered crocodile was C. niloticus ( $94 \%$ of sightings) with population structure highly biased to individuals $<1$ year of age (41.4\%). Only 14 M. cataphractus were observed. Local informants report that crocodiles were more common $10-20$ years ago than at present. There is now little commercial harvest, which includes limited use in the bushmeat and traditional medicine markets, because of the crocodile's scarcity. Habitat encroachment and incidental bycatch in fishing devices appear to be the major threats. Actions needed to improve the conservation status of crocodile populations in both countries, and throughout the region, are discussed.
\end{abstract}

Keywords Bushmeat, Côte-d'Ivoire, crocodile, Crocodylus, fishery, Ghana, Mecistops, Osteolaemus.

\section{Introduction}

Crocodilians are charismatic megafauna that act as keystone species and often serve as indicators in ecosystem monitoring and restoration programmes (Ross, 1998; Mazzotti et al., 2007). They are widely viewed as flagship conservation species and have the potential to galvanize efforts in wetlands conservation. Three species are native to West Africa: the Nile crocodile Crocodylus niloticus, the slender-snouted crocodile Mecistops cataphractus, and the

Matthew H. Shirley (Corresponding author) Department of Wildlife Ecology \& Conservation, University of Florida, 110 Newins-Ziegler Hall, Gainesville, FL 32611-0430, USA. E-mail mshirley@ufl.edu

William Oduro Department of Wildlife \& Range Management, College of Agriculture and Natural Resources, Kwame Nkrumah University of Science and Technology, Kumasi, Ghana.

Hilaire YАококоRe Beibro Laboratoire de Zoologie et de Biologie Animale, UFR Biosciences, Université de Cocody-Abidjan, Abidjan, Côted'Ivoire.

Received 5 September 2007. Revision requested 30 November 2007. Accepted 8 January 2008.
African dwarf crocodile Osteolaemus tetraspis. A rich cultural history has included both worship and overexploitation (Moiser \& Barber, 1994; Kpera, 2003; Toonen, 2003) but there is an almost complete deficit of knowledge regarding ecology and population status of crocodiles across the region (Ross, 1998).

Although the Nile crocodile is one of the most widely studied crocodilians it has been little studied in West and Central Africa (Pooley, 1980; Ross, 1998). Most of the limited information available consists only of presence/ absence information (Wilson, 1978; Pooley, 1980; Kofron, 1992; Behra, 1993, 1994; Moiser \& Barber, 1994; Dore, 1996; Even, 1996; Akani et al., 1998; de Smet, 1999; Luiselli et al., 2000; Shine et al., 2001; Kpera, 2003). Recent debate on the taxonomic status of this crocodile in West and Central Africa has highlighted the importance of understanding its population status (Schmitz et al., 2003; Hekkala, 2004). It is categorized as Lower Risk/least concern on the IUCN Red List (IUCN, 2008) but all West African populations are in CITES Appendix I (UNEP-WCMC, 2008). The IUCN Crocodile Specialist Group noted that surveys throughout this region are the highest priority for Nile crocodile conservation (Ross, 1998).

The slender-snouted crocodile is regarded by the Crocodile Specialist Group as the least known crocodilian (Ross, 1998). Until recently it was considered to be a true crocodile, in the genus Crocodylus, but has now been placed in the monotypic genus Mecistops (McAliley et al., 2006). In certain parts of its range (Gabon and Republic of Congo) it may still be relatively common (Thorbjarnarson \& Eaton, 2004), although the most recent surveys in West Africa (Waitkuwait 1985a,b, 1989) suggested that populations are seriously declining. The slender-snouted crocodile is categorized as Data Deficient on the Red List (IUCN, 2008) but the Crocodile Specialist Group has expressed concern that it may meet the criteria for Endangered (Ross, 1998), and all populations are on CITES Appendix I (UNEP-WCMC, 2008). The highest priority action for this species is surveys of population status throughout its range to determine its Red List status and establish conservation programmes (Ross, 1998).

The African dwarf crocodile is a poorly known species ranging throughout the lowland forest zone of West and Central Africa and inhabits forest waterways, swamp forests and isolated savannah pools (Kofron \& Steiner, 1994; Ross, 1998; Riley \& Huchzermeyer, 1999). Like the Nile crocodile, its taxonomic status is uncertain, with a second taxon, Osteoblepharon osbornii, described for animals 
from the western Congo basin (Thorbjarnarson \& Eaton, 2004). The dwarf crocodile is cateogrized as Vulnerable on the Red List (IUCN, 2008) and all populations are on CITES Appendix I (UNEP-WCMC, 2008). Range-wide status surveys and evaluation of the threat from the bushmeat trade are priority actions for this species (Ross, 1998).

The objective of this study was to survey the distribution, population status and threats facing the slendersnouted and Nile crocodiles in Ghana and Côte-d'Ivoire, and to collect data opportunistically on the African dwarf crocodile.

\section{Study area}

From 19 July to 27 November 2006 we surveyed the status, distribution and threats faced by crocodiles in Ghana and Côte-d'Ivoire (Fig. 1). The southern portion of both countries is mostly Upper Guinea Forest, whereas the northern portion is largely wooded savannah. In both countries the major wet season is in March-June, a short dry season in August, and a second, reduced wet season from September to mid November. There is a unimodal rainfall regime in the northern savannah zone from May/ June to November (Grubb, 1998). The average day and night temperatures during the study were $26^{\circ} \mathrm{C}$ and $23^{\circ} \mathrm{C}$, respectively. Our surveys were conducted during the latter half of the normal wet season, although drought conditions characterized 2006 and crocodiles were still limited to areas of permanent water.

Surveys were planned systematically according to information from published records, anecdotal reports, and presumed suitable crocodile habitats. Significant effort was made to sample broadly within each country to obtain information over a wide range of habitat types, land uses, and protection status. Political instability prohibited us from surveying the northern half of Côte-d'Ivoire (Fig. 1).

\section{Methods}

Initial surveys detected low crocodile densities and we therefore decided to spend less time at each site and sample more sites (Thompson, 2004). Surveys were conducted from available water craft and on foot. Diurnal surveys were utilized to detect basking crocodiles and plan nocturnal survey routes. Nocturnal spotlight surveys are a standard crocodilian survey method (Webb \& Smith, 1987); crocodiles were detected with LED headlamps or a 100,000/ 200,000 candlepower flood/spotlight. Length of survey

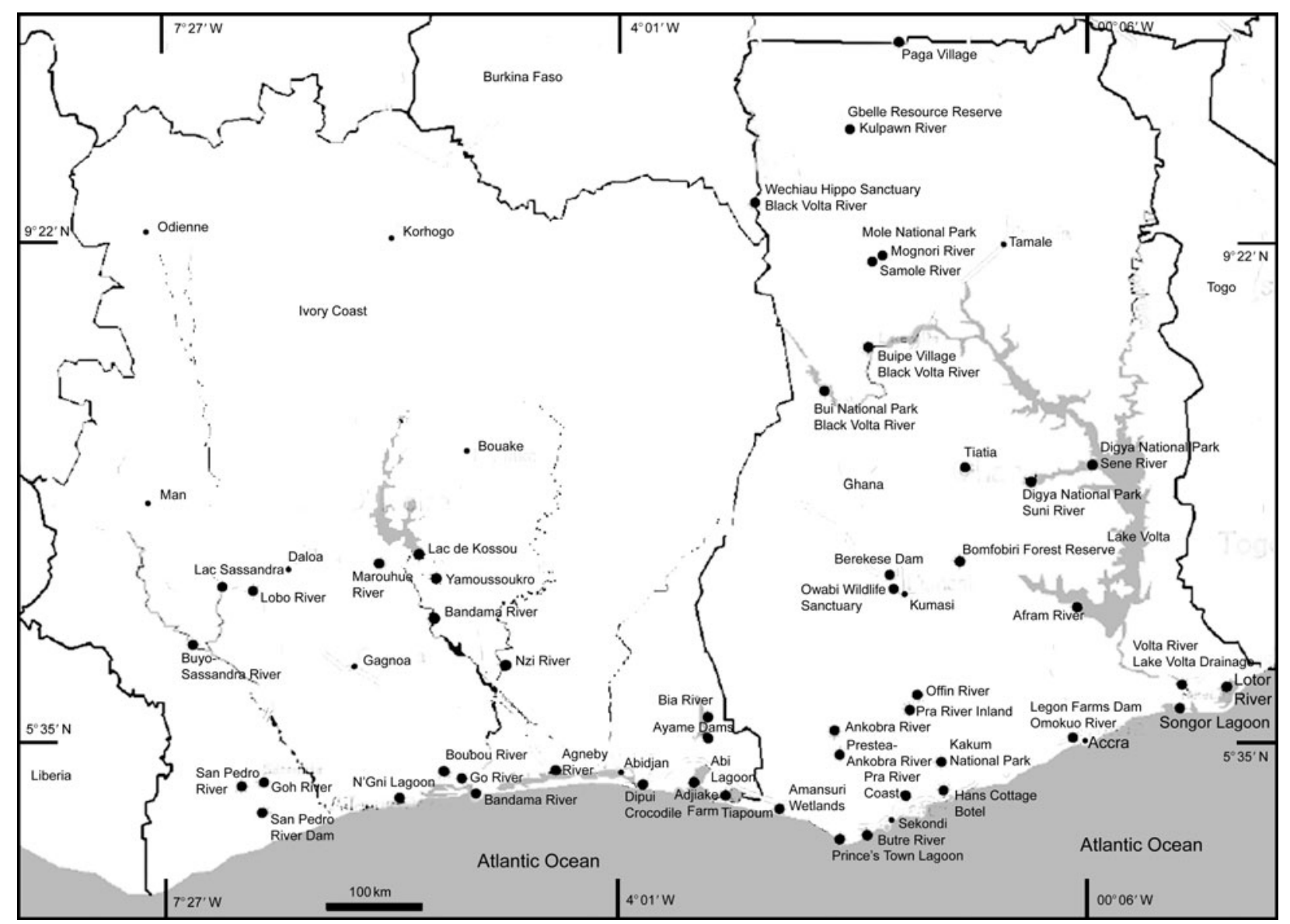

FIG. 1 Locations surveyed for crocodiles in Ghana and Côte d'Ivoire (large dots). Small dots represent cities. 
routes was calculated using a global positioning system. This survey method results in an index of relative encounter rate because on any given survey not all individuals of a population are detectable (Bayliss, 1987; Hutton \& Woolhouse, 1989; Thorbjarnarson et al., 2000).

Survey sites were characterized as river, flood plain (i.e. river or stream in wooded savannah habitat that flooded into the surrounding plain), natural lakes, artificial dams, coastal lagoons, wetlands (e.g. swamp forest), and urban or other artificial habitats. When spotted, crocodiles were approached to determine species and estimate total length in the following size classes: hatchling, $<1.0 \mathrm{~m}, 1.1>3.5 \mathrm{~m}$ in $0.25 \mathrm{~m}$ increments, and EO (eyes only) for unapproachable individuals. While it is impossible to assign EO individuals to a species with complete confidence location, behaviour, size and other sightings allow some to be provisionally assigned. Unless otherwise stated, all crocodile encounters (both counts and rates) are presented as the number of non-hatchling crocodiles.

Information on crocodile hunting was obtained from market and vendor/hunter surveys, principally at the Kumasi Central Market in Ghana, with additional information collected at the Tamale Market in Ghana, the Dimbokro Central Market in Côte-d'Ivoire, and villages during the surveys. Hunters, fishermen and village councils were informally interviewed regarding perceptions of pres- ent and historical crocodile abundance, relative value of, or preference for, crocodile products (consumption, traditional medicinal and religion), and human-crocodile conflict.

\section{Results}

Seventy-one crocodile surveys were conducted at 46 different sites covering $726.4 \mathrm{~km}$ of crocodile habitat (Table 1): 25 sites $(\mathrm{n}=46$ surveys, $333.7 \mathrm{~km})$ in Ghana and 21 sites $(\mathrm{n}=25$ surveys, $402.2 \mathrm{~km})$ in Côte-d'Ivoire. Over $57 \%$ of surveys $(\mathrm{n}=41,440.3 \mathrm{~km})$ were in riverine habitat yet only $36.5 \%(\mathrm{n}=100)$ of crocodile sightings were in rivers. In contrast, $11 \%$ of surveys $(\mathrm{n}=8,137.3 \mathrm{~km})$ were coastal lagoons, yet $31 \%(n=85)$ of crocodiles were sighted there (Table 1). No crocodiles were observed in $31.5 \%$ of surveys, and $<5$ crocodiles were observed in $71 \%$ of surveys $\left(\right.$ median encounter rate $=0.26 \mathrm{~km}^{-1}$ ).

We encountered 454 individual crocodilians (Tables $2 \& 3$ ) that ranged in size from hatchlings to $<3.5 \mathrm{~m}$ in length (Tables 2 \& 3). Over $84 \%$ of crocodiles whose sizes were determined were $\leq 1.5 \mathrm{~m}$ (i.e. not sexually mature). The combined, non-species specific mean encounter rate for all surveys was $0.90 \mathrm{~km}^{-1}$ (1.184 and $0.433 \mathrm{~km}^{-1}$ in Ghana and Côte-d'Ivoire, respectively). However, for sites where only non-hatchling crocodiles were detected the mean

TABLE 1 Survey details by habitat type. Survey distance is the combined length of surveys, with average survey length and percent of total distance for each habitat type. Crocodile sightings are presented as the number of non-hatchlings, with average number of nonhatchlings per survey and the percentage of sightings of non-hatchlings per habitat, and total including hatchlings. Encounter rate is the average for non-zero encounter surveys, with average for all surveys per habitat. Zero encounter is the number of surveys where only hatchlings were encountered, with number of surveys with no encounters and percentage of no encounter surveys of the total surveys per habitat.

\begin{tabular}{|c|c|c|c|c|c|c|c|}
\hline & \multicolumn{6}{|c|}{ Habitat type } & \multirow[b]{2}{*}{ Total } \\
\hline & Rivers & Flood plain & Lakes/dams & Coastal lagoons & Wetland & Urban/artificial & \\
\hline \multicolumn{8}{|l|}{ Surveys } \\
\hline No. & 41 & 4 (1 site) & 10 & 11 & 2 (1 site) & 3 & 71 \\
\hline$\%$ of total & 57.8 & 5.6 & 14.1 & 15.5 & 2.8 & 4.2 & 100 \\
\hline \multicolumn{8}{|l|}{ Survey distance } \\
\hline $\mathrm{Km}$ & 440.3 & 6.2 & 126.3 & 137.3 & 13 & 3.35 & 726.4 \\
\hline Mean & 10.3 & 1.6 & 14 & 17.2 & 6.5 & 1.11 & 8.52 \\
\hline$\%$ of total & 60.6 & 0.85 & 17.4 & 18.9 & 1.8 & 0.46 & 100 \\
\hline \multicolumn{8}{|c|}{ Crocodile sightings } \\
\hline Non-hatchlings & 100 & 34 & 32 & 85 & 4 & 19 & 274 \\
\hline Mean & 2.4 & 8.5 & 3.5 & 10.6 & 2 & 6.3 & 5.58 \\
\hline$\%$ of total & 36.5 & 12.4 & 11.7 & 31 & 1.5 & 6.9 & 100 \\
\hline Total & 160 & 38 & 48 & 130 & 25 & 53 & 454 \\
\hline \multicolumn{8}{|l|}{ Encounter rate } \\
\hline Non-zero & 0.77 & 7.13 & 1.43 & 0.6 & 0.43 & 11.89 & 0.9 \\
\hline All & 0.45 & 7.13 & 0.63 & 0.52 & 0.43 & 11.89 & 1.41 \\
\hline \multicolumn{8}{|l|}{ Zero encounter } \\
\hline Hatchlings only & 17 & 0 & 5 & 1 & 0 & 0 & 23 \\
\hline No encounters & 16 & 0 & 5 & 1 & 0 & 0 & 22 \\
\hline$\%$ of total & 39 & 0 & 55.6 & 12.5 & 0 & 0 & 31.5 \\
\hline
\end{tabular}


TABLE 2 Survey results for confirmed C. niloticus sightings and unidentified sightings presumed to be C. niloticus in Ghana and Côte-d'Ivoire. Encounters are in estimated size class by site. Total effective represents the number of non-hatchlings seen in each survey. Average encounter rates include only surveys that detected crocodiles.

\begin{tabular}{|c|c|c|c|c|c|c|c|c|c|c|c|c|c|c|c|c|c|}
\hline \multirow[b]{2}{*}{ Dates } & \multirow[b]{2}{*}{ Location } & \multicolumn{12}{|c|}{ Estimated size $(\mathrm{m})$} & \multirow[b]{2}{*}{$\begin{array}{l}\text { Total } \\
\text { observed }\end{array}$} & \multirow[b]{2}{*}{$\begin{array}{l}\text { Total } \\
\text { effective }\end{array}$} & \multirow{2}{*}{$\begin{array}{l}\text { Survey } \\
\text { distance } \\
(\mathrm{km})\end{array}$} & \multirow[b]{2}{*}{$\begin{array}{l}\text { Encounter } \\
\text { rate }\end{array}$} \\
\hline & & Htch. ${ }^{1}$ & $<1.0$ & $\begin{array}{l}1.0- \\
1.25\end{array}$ & $\begin{array}{l}1.25- \\
1.5\end{array}$ & $\begin{array}{l}1.5- \\
1.75\end{array}$ & $\begin{array}{l}1.75- \\
2.0\end{array}$ & $\begin{array}{l}2.0- \\
2.25\end{array}$ & $\begin{array}{l}2.25- \\
2.5\end{array}$ & $\begin{array}{l}2.5- \\
2.75\end{array}$ & $\begin{array}{l}2.75- \\
3.0\end{array}$ & $\begin{array}{l}3.0- \\
3.5\end{array}$ & $?^{2}$ & & & & \\
\hline \multicolumn{18}{|l|}{ Ghana } \\
\hline 20 July 2006 & Mole - Mognori River & & & & & & & & & & & & 1 & 1 & 1 & 3.7 & 0.27 \\
\hline 21-22 July 2006 & Mole - Samole Stream & 4 & & & 1 & & & 3 & 1 & & & & 28 & 37 & 33 & 5.2 & 6.35 \\
\hline 24 July 2006 & Mole - Lovi River & 1 & & & 1 & & & & & & & & 1 & 3 & 2 & 2.3 & 0.89 \\
\hline 29-30 July 2006 & Black Volta - WHS & & & 1 & & & & & & & & & 1 & 2 & 2 & 15.2 & 0.13 \\
\hline 31 July 2006 & Village Dam - WHS ${ }^{3}$ & 30 & 1 & & 1 & & 2 & & & & & & & 34 & 4 & 0.2 & 26.67 \\
\hline 2-4 Aug. 2006 & Kulpawn River & 45 & 4 & 5 & & & & & & & & & 20 & 74 & 29 & 15.0 & 1.93 \\
\hline 9 Aug. 2006 & Tiatia, Attebubu ${ }^{3}$ & 4 & 3 & & 1 & & & & & & & & & 8 & 4 & 1.0 & 4.00 \\
\hline 10-11 Aug. 2006 & Suni River & & 1 & & 1 & & & & & & & & & 2 & 2 & 82.3 & 0.02 \\
\hline 22 Aug. 2006 & Afram River & & & & & & & & & & & & 5 & 5 & 5 & 4.1 & 1.22 \\
\hline 26-29 Aug. 2006 & Black Volta - BNP & 8 & 1 & 2 & & & & & & & & & 10 & 21 & 13 & 36.2 & 0.36 \\
\hline 30 Sep. 2006 & Legon Dam & & 2 & 2 & 5 & & 1 & 1 & 1 & & & & 8 & 20 & 20 & 11.0 & 1.82 \\
\hline 5 Oct. 2006 & Butre River & & 1 & & 1 & & & & & & & & 2 & 4 & 4 & 9.0 & 0.44 \\
\hline 11 Oct. 2006 & Amansuri Wetlands & 21 & 1 & & 3 & & & & & & & & & 25 & 4 & 13.0 & 0.31 \\
\hline \multirow[t]{3}{*}{14 Oct. 2006} & Prince's Town Lagoon & & & 1 & 2 & 1 & & & & & & & & 4 & 4 & 7.0 & 0.57 \\
\hline & Total/average & 113 & 14 & 11 & 16 & 1 & 3 & 4 & 2 & 0 & 0 & 0 & 76 & 240 & 127 & 205.1 & 3.21 \\
\hline & $\% /$ average & $47.1 \%$ & $5.8 \%$ & $4.6 \%$ & $6.7 \%$ & $0.4 \%$ & $1.3 \%$ & $1.7 \%$ & $0.8 \%$ & $0.0 \%$ & $0.0 \%$ & $0.0 \%$ & $31.7 \%$ & 18.15 & 9.07 & 14.65 & 1.193 \\
\hline \multicolumn{18}{|l|}{ Côte-d'Ivoire } \\
\hline 22-27 Oct. 2006 & Abi Lagoon & 40 & 12 & 9 & 5 & 5 & 2 & 1 & 1 & 2 & 3 & 2 & 25 & 107 & 67 & 78.1 & 0.86 \\
\hline 5 Nov. 2006 & Bandama River & 1 & & & & & & & & & & & & 1 & 0 & 16.2 & 0.00 \\
\hline 8 Nov. 2006 & Yamoussoukro & & & & 2 & 1 & 2 & 1 & & & & & 5 & 11 & 11 & 2.2 & 5.00 \\
\hline 10 Nov. 2006 & Lobo River & & & & & & & & & & & & 1 & 1 & 1 & 3.2 & 0.31 \\
\hline 18 Nov. 2006 & San Pedro Dam & 16 & 11 & & & & & & & & & & & 27 & 11 & 7.2 & 1.53 \\
\hline 23 Nov. 2006 & N’Gni Lagoon & & 3 & 2 & 1 & & & & & & & & 5 & 11 & 11 & 38.5 & 0.29 \\
\hline 24 Nov. 2006 & Boubou River & 1 & 1 & & & & 1 & & & & & & 3 & 6 & 5 & 28.3 & 0.18 \\
\hline 25 Nov. 2006 & Go River & & 2 & 1 & 1 & & & & 1 & & & & 4 & 9 & 9 & 27.6 & 0.33 \\
\hline 26 Nov. 2006 & Bandama River & & & 1 & 1 & & 1 & & 1 & & & & & 4 & 4 & 36.2 & 0.11 \\
\hline \multirow[t]{5}{*}{27 Nov. 2006} & Agneby River & 5 & & & & & 1 & 2 & & & & & & 8 & 3 & 13.6 & 0.22 \\
\hline & Total/average & 63 & 29 & 13 & 10 & 6 & 7 & 4 & 3 & 2 & 3 & 2 & 43 & 185 & 122 & 251.1 & \\
\hline & $\% /$ average & $34.1 \%$ & $15.7 \%$ & $7.0 \%$ & $5.4 \%$ & $3.2 \%$ & $3.8 \%$ & $2.2 \%$ & $1.6 \%$ & $1.1 \%$ & $1.6 \%$ & $1.1 \%$ & $23.2 \%$ & 18.50 & 12.20 & 25.11 & 0.882 \\
\hline & Overall total & 176 & 43 & 24 & 26 & 7 & 10 & 8 & 5 & 2 & 3 & 2 & 119 & 425 & 249 & 456.2 & 2.24 \\
\hline & Overall \%/average & $41.4 \%$ & $10.1 \%$ & $5.6 \%$ & $6.1 \%$ & $1.6 \%$ & $2.4 \%$ & $1.9 \%$ & $1.2 \%$ & $0.5 \%$ & $0.7 \%$ & $0.5 \%$ & $28.0 \%$ & 17.71 & 10.38 & 19.01 & 1.05 \\
\hline
\end{tabular}

${ }^{1} \mathrm{Htch}$, hatchlings

${ }^{2}$ Unidentified sightings presumed to be C. niloticus

${ }^{3}$ Surveys removed from the total average encounter rates due to their non-natural site status. 
TABLE 3 Survey results for confirmed M. cataphractus and O. tetraspis sightings and unidentified sightings presumed to be one of these species. Encounters are in estimated size class by site. Total effective is the number of non-hatchlings seen in each survey. Average encounter rates include only surveys that detected crocodiles.

\begin{tabular}{|c|c|c|c|c|c|c|c|c|c|c|c|c|c|c|c|}
\hline \multirow[b]{2}{*}{ Dates } & \multirow[b]{2}{*}{ Location } & \multirow[b]{2}{*}{ Country } & \multicolumn{9}{|c|}{ Estimated size (m) } & \multirow[b]{2}{*}{$\begin{array}{l}\text { Total } \\
\text { observed }\end{array}$} & \multirow[b]{2}{*}{$\begin{array}{l}\text { Total } \\
\text { effective }\end{array}$} & \multirow[b]{2}{*}{$\begin{array}{l}\text { Survey } \\
\text { distance }(\mathrm{km})\end{array}$} & \multirow[b]{2}{*}{$\begin{array}{l}\text { Encounter } \\
\text { rate }\end{array}$} \\
\hline & & & Htch. $^{1}$ & $>$ Htch. $^{1}$ & $<1.0$ & $\begin{array}{l}1.0- \\
1.25\end{array}$ & $\begin{array}{l}1.25- \\
1.5\end{array}$ & $\begin{array}{l}1.5- \\
1.75\end{array}$ & $\begin{array}{l}1.75- \\
2.0\end{array}$ & $\begin{array}{l}2.0- \\
4.0\end{array}$ & $?^{2}$ & & & & \\
\hline \multicolumn{16}{|l|}{ M. cataphractus } \\
\hline 20 July 2006 & Mole - Mognori River & Ghana & & & 1 & & & & & & 2 & 3 & 3 & 3.7 & 0.811 \\
\hline 20 July 2006 & Mole - Samole Stream & Ghana & & & & & & & 1 & & & 1 & 1 & 1.0 & 1.000 \\
\hline 30 Aug. 2006 & Offin River & Ghana & 1 & & & & & & & & & 1 & 0 & 6.5 & 0.000 \\
\hline 16 Nov. 2006 & Goh River & Côte-d'Ivoire & & & 5 & & & & & & 2 & 7 & 7 & 1.8 & 3.889 \\
\hline 24 Nov. 2006 & Boubou River & Côte-d'Ivoire & 1 & & & & & & & & & 1 & 0 & 28.3 & 0.000 \\
\hline \multirow[t]{3}{*}{26 Nov. 2006} & Bandama River & Côte-d'Ivoire & & & & & & 1 & & & & 1 & 1 & 36.2 & 0.028 \\
\hline & & Total & 5 & 0 & 5 & 0 & 0 & 1 & 1 & 0 & 2 & 14 & 9 & & 0.955 \\
\hline & & $\% /$ average & $35.7 \%$ & $0.0 \%$ & $35.7 \%$ & $0.0 \%$ & $0.0 \%$ & $7.1 \%$ & $7.1 \%$ & $0 \%$ & $14.3 \%$ & $3.1 \%^{3}$ & 2.00 & $0.0193^{4}$ & $0.027^{5}$ \\
\hline \multicolumn{16}{|l|}{ O. tetraspis } \\
\hline 14 Aug. 2006 & Owm River, BFR & Ghana & & & 2 & & & & & & & 2 & 2 & 2.3 & 0.870 \\
\hline 17 Aug. 2006 & Owabi Wildlife Sanctuary & Ghana & & & & & 1 & & & & & 1 & 1 & 6.7 & 0.149 \\
\hline 23 Oct. 2006 & Abi Lagoon & Côte-d'Ivoire & 1 & & & & & & & & & 1 & 0 & 27.2 & 0.000 \\
\hline 4-5 Nov. 2006 & Bandama River & Côte-d'Ivoire & & & 1 & & 2 & 3 & & & & 6 & 6 & 24.7 & 0.243 \\
\hline 10 Nov. 2006 & Lobo River & Côte-d'Ivoire & & & & & 1 & & & & & 1 & 1 & 3.2 & 0.313 \\
\hline \multirow[t]{3}{*}{13 Nov. 2006} & Sassandra River & Côte-d'Ivoire & & & & & & 2 & & & & 2 & 2 & 6.9 & 0.290 \\
\hline & & Total & 1 & 0 & 3 & 0 & 4 & 5 & 0 & 0 & 0 & 13 & 12 & & 0.311 \\
\hline & & $\% /$ average & $7.7 \%$ & $0.0 \%$ & $23.1 \%$ & $0.0 \%$ & $30.8 \%$ & $38.5 \%$ & $0.0 \%$ & $0 \%$ & $0.0 \%$ & $2.9 \%^{3}$ & 2.00 & $0.0179^{4}$ & $0.025^{5}$ \\
\hline
\end{tabular}

${ }^{1} \mathrm{Htch}$, hatchlings

${ }^{2}$ Unidentified sightings presumed to be either M. cataphractus or O. tetraspis

${ }^{3}$ Percentage known sightings for each species from the total number of crocodiles detected

${ }^{4}$ Average encounter rate for each species over all surveys (including zero-encounter surveys)

${ }^{5}$ Average encounter rate for each species over all non-zero surveys (i.e. where any of the three crocodiles were detected) 
encounter rate was $1.41 \mathrm{~km}^{-1}$ (1.821 and $0.712 \mathrm{~km}^{-1}$ in Ghana and Côte-d'Ivoire, respectively).

C. niloticus was the most frequently encountered species, with 301 confirmed individual sightings and 124 of the assigned EO sightings (Table 2). Individuals ranged in size from hatchlings to $<3.5 \mathrm{~m}$. However, only $8.8 \%(\mathrm{n}=37)$ of individuals fell in potentially sexually reproductive size classes $(>1.5 \mathrm{~m})$ and most were detected at just a few sites. Where detected, $C$. niloticus was encountered on average at a rate of $1.05 \mathrm{~km}^{-1}\left(1.193\right.$ and $0.882 \mathrm{~km}^{-1}$ in Ghana and Côted'Ivoire, respectively). C. niloticus was found almost exclusively in northern, savannah woodland rivers and dams or in coastal lagoons and rivers.

$M$. cataphractus was rarely encountered, with 10 sightings and four presumed EO sightings (Table 3 ). Individuals ranged in size from hatchling to $<2 \mathrm{~m}$, and only two confirmed individuals were in a potentially reproductive size class $(>1.5 \mathrm{~m})$. M. cataphractus was encountered at $0.029 \mathrm{~km}^{-1}$ over all non-zero encounter surveys, $0.468 \mathrm{~km}^{-1}$ where both $C$. niloticus and M. cataphractus were detected sympatrically, and $3.89 \mathrm{~km}^{-1}$ where only $M$. cataphractus was found. M. cataphractus was found primarily in forested rivers in the southern forest belt of each country, although its presence in northern rivers with gallery forest indicates broader habitat use than formerly presumed.

O. tetraspis was also rarely encountered, with 11 sightings and two EO sightings (Table 3). Individuals ranged in size from hatchling to $1.75 \mathrm{~m}$, and $69.3 \%$ of encountered individuals were in a potentially reproductive size class $\left(>_{1.25} \mathrm{~m}\right)$. Where detected, O. tetraspis was encountered at $0.311 \mathrm{~km}^{-1}$. These survey results are not representative of the true abundance of $O$. tetraspis as the survey strategy was directed at finding the other two species and O. tetraspis was mainly observed during incidental excursions into tributaries and forest habitat unsuitable for the other species. Anecdotal evidence suggests that O. tetraspis remains abundant throughout both countries.

Interviews with market vendors suggested that crocodiles are rarely sold in major bushmeat markets. Market patrons and community members offered biological, cultural, and social reasons and indicated that crocodiles are rarely hunted and even more rarely sold for consumption when captured. Four crocodile hunters were encountered, although all claimed to have not hunted crocodiles in at least 10 years (in one case $>20$ years) because of crocodile scarcity. Only three instances of attacks on humans were encountered, only one of which was fatal, and there were only two records within the past 15 years. Human-crocodile conflict is limited to rare predation on domestic livestock.

\section{Discussion}

The result of most immediate concern is the few encounters with M. cataphractus. Both Ghana and Côte-d'Ivoire are within the reported species range and historically had dense patches of tropical forest and well-forested river margins (Ross, 1998). However, because of rapid loss and fragmentation of the Upper Guinea Forests (Hawthorne, 1996; Fairhead \& Leach, 1998; Oates, 1999; Myers et al., 2000) it is now likely that these countries represent the western edge of the modern range of $M$. cataphractus. The reported range extends west to Senegal and, whilst this may still be the case, populations are probably heavily depleted west of Côte-d'Ivoire and we suggest that the core range for this species is contracting east into the Congo Basin. It is therefore likely that the observed low densities of $M$. cataphractus and seemingly abnormal habitat use (i.e. savannah woodland) are range limit effects. Additionally, it is possible that the more abundant $C$. niloticus limits the distribution and abundance of $M$. cataphractus, a phenomenon unlikely to occur in Central Africa because of the low abundance of $C$. niloticus there (M. Eaton, pers. comm.).

The spotlight surveys found that crocodiles were usually present at low densites. Encounter rates from this study are among the lowest reported for crocodiles throughout Africa, and of particular note is the high proportion of zero-encounter surveys. Compared to surveys in East and southern Africa, where some encounter rates may be low, few surveys detect no crocodiles (Table 4 ). While it is impossible to quantify current population trends because of a lack of historical data, information from the interviews suggests that populations are in decline. Local reports indicated that as recently as the 1980 os crocodiles could be encountered frequently, and at most sites populations were robust enough to be hunted. The apparently depleted crocodile populations in Ghana and Côte-d'Ivoire are in contrast to reports from East and southern Africa where populations have been evaluated for their harvest value and in many areas have recovered significantly (NPWS, 1993; Changwe, 1996, 2004; Jachmann, 1996; Leslie, 1997; Nyirenda, 1997, 2004; Games \& Severre, 1999; Brown et al., 2004; Kampamba, 2004; Simwanza, 2004; Zimbabwe Parks and Wildlife Management Authority, 2006).

Of the major threats facing crocodilians in West Africa habitat loss and encroachment probably have the greatest effects. Habitat loss is probably having the greatest impact on the forest-river dwelling $M$. cataphractus, with loss of the Upper Guinea Forests limiting available habitat. Habitat encroachment, where human settlements invade potential crocodile habitat, affects all three species by limiting available nesting and basking habitat (only a single crocodile was seen basking during the day).

The second major anthropogenic threat facing crocodilians is overfishing. Fishers in this region report small catches, in weight and volume (Brashares et al., 2004; M.H. Shirley, pers. obs.), suggesting a heavily depleted fishery that will affect crocodiles by depleting prey resources and increasing the rate of incidental mortality through drowning 
TABLE 4 Encounter rates (individuals $\mathrm{km}^{-1}$ ) for C. niloticus from across its eastern and southern African distribution for comparison with the results of this study. Encounter rates are comparable because standardized survey methods were used.

\begin{tabular}{|c|c|c|c|c|}
\hline Site & Survey year & Habitat & Encounter rate & Source \\
\hline \multicolumn{5}{|l|}{ Namibia } \\
\hline Kwandu River & 2004 & River & 1.83 & Brown et al. (2004) \\
\hline Zambezi River System & 2004 & River & 0.55 & Brown et al. (2004) \\
\hline \multicolumn{5}{|l|}{ South Africa } \\
\hline St. Lucia & 1994 & River & 4.90 & Leslie (1997) \\
\hline \multicolumn{5}{|l|}{ Tanzania } \\
\hline Grumeti River & 1999 & River & 1.24 & Games \& Severre (1999) \\
\hline Mara River & 1999 & River & 0.33 & Games \& Severre (1999) \\
\hline Ruaha River & 1999 & River & 2.42 & Games \& Severre (1999) \\
\hline Ruaha River & 1999 & River & 2.27 & Games \& Severre (1999) \\
\hline Rufiji & 1999 & River & 16.90 & Games \& Severre (1999) \\
\hline Ulanga & 1999 & River & 3.55 & Games \& Severre (1999) \\
\hline \multicolumn{5}{|l|}{ Zambia } \\
\hline Luangwa & 1996 & River & 17.90 & Changwe (1996) \\
\hline Luangwa & 1996 & River & 13.60 & Jachmann (1996) \\
\hline Luangwa & 1997 & River & 18.00 & Nyirenda (1997) \\
\hline Luangwa & 2003 & River & 22.20 & Changwe (2004) \\
\hline Lower Zambezi River & 2003 & River & 5.25 & Nyirenda (2004) \\
\hline Kafue River & 2003 & River & 3.10 & Kampamba (2004) \\
\hline Upper Zambezi River & 2003 & River & 1.78 & Nyirenda (2004) \\
\hline Tanganyika & 2003 & Lakes & 0.89 & Simwanza (2004) \\
\hline Bangweulu and Chiunabulu & 2003 & Lakes & 0.02 & Simwanza (2004) \\
\hline Mweru & 2003 & Lakes & 0.01 & Simwanza (2004) \\
\hline Mweru-Wantipa System & 2004 & Lakes & 0.08 & Simwanza (2004) \\
\hline Itezhi-tezhi & Unknown & Unknown & 12.00 & NPWS (1993) \\
\hline Kariba & Unknown & Unknown & 12.00 & NPWS (1993) \\
\hline \multicolumn{5}{|l|}{ Zimbabwe } \\
\hline Zambezi River & 2001 & River & 9.70 & $\begin{array}{l}\text { Zimbabwe Parks and } \\
\text { Management Authority (2006) }\end{array}$ \\
\hline
\end{tabular}

in fishing nets. Finally, while hunting does not seem to be a current phenomenon (see below), commercial hunting was at one time common and the depauperate crocodile populations today could, at least partially, be a result of this historical trade that, in combination with the other current threats, limits the ability of populations to rebound despite evidence of breeding from the presence of hatchlings and juveniles.

Throughout Central Africa (Gabon, Democratic Republic of Congo, Republic of Congo and Equatorial Guinea), crocodiles are currently hunted for the bushmeat trade. In Ghana and Côte-d'Ivoire, crocodile hunting appeared to be a limited phenomenon until the 1980 s and early 1990s in certain localities, although primarily for skins, traditional medicine and religious uses. Crocodile harvest is now rare because of a combination of scarcity of crocodiles, collapse of the local market for crocodile products, traditional beliefs, and stricter international trade regulations (e.g. CITES).

Our results show that crocodiles are rarely encountered and when encountered the predominant size class is hatchling and juveniles, making individuals too small to be worth hunting on a regular basis. Although we do not expect equal detectability amongst all size classes, our inability to detect adult and subadult crocodiles is probably also a problem for bushmeat hunters. This scarcity of crocodiles has also led to a decline in the supply for crocodile products, which has led to a large-scale market reduction and social de-emphasis on crocodile hunting. Interviews with people from throughout the bushmeat supply chain and with bushmeat consumers confirmed both the lack of supply and demand for crocodile products (M.H. Shirley, unpubl. data). This is corroborated by other bushmeat studies that only found insignificant and irregular records of crocodiles in major markets (Ghana Wildlife Division, 1998a,b; Holbech undated, 2001; Conservation International, 2002; Mendelson et al., 2003; Brashares et al., 2004; Bassett, 2005; Cowlishaw et al., 2005a,b; Crookes et al., 2005; Damania et al., 2005; Rowcliffe et al., 2005; E.J. Milner-Gulland, pers. comm.; Ghana Wildlife Society, undated.).

The cultural history associated with crocodiles in this region is complex, and most ethnic groups have at least some religious or historical attachment to them. Many people believe the persistence of water is tied directly to crocodiles, and if the crocodiles vanish the rivers will run 
dry. Crocodiles were worshipped as totems and used as guardians of community grain stores. This is exemplified in the village of Paga in Ghana, which has a well known community-based tourism programme centred on the cultural relationship with crocodiles. Additionally, crocodile bile is widely believed to be a potent toxin and because of this many people are wary of buying crocodile meat. However, we did encounter a small number of crocodiles for sale in the form of skins, skulls, and teeth in traditional religion and medicine market stalls, and three households with live pet crocodilians.

We recommend continuing research programmes to examine the distribution, population status, ecology and conservation status of crocodilians in the region. Priorities are to identify key localities for long-term monitoring and sites for future ex situ conservation actions (e.g. repopulation from captive stock). Surveys in Ghana and southern Côte-d'Ivoire need to be repeated in the dry season to determine the impact of environmental conditions on survey results, and new surveys need to be carried out in protected areas throughout Côte-d'Ivoire (Parc Nacional du Tai, Parc Nacional du Comoe and Parc Nacional d'Azagny), as well as in Nigeria, Liberia, Sierra Leone, Guinea-Bissau, Guinea, The Gambia and Senegal. Emphasis should be placed on discovering populations of $M$. cataphractus and understanding the status of $O$. tetraspis throughout the region.

Our results suggest that the IUCN Red List category for M. cataphractus should be re-evaluated. Under the IUCN criteria, a species qualifies for Data Deficient 'where data are so uncertain that any category is plausible' (IUCN, 2001, 2007). Surveys in Liberia (Kofron, 1992), Nigeria (Dore, 1996; Akani et al., 1998; Luiselli et al., 200o), Senegal and Gambia (M.H. Shirley, unpubl. data), and our studies in Ghana and Côte d'Ivoire, countries that hold the last remaining blocks of Upper Guinea Forest, suggest that $M$. cataphractus in West Africa qualifies for Endangered under criteria $\mathrm{A} 1 \mathrm{abcd}+2+3+4 \mathrm{C} 1+2 \mathrm{a}(\mathrm{i})$ and may even qualify for Critically Endangered under criteria Alabcd $+2+3+4$ (IUCN, 2001). We propose that a formal regional assessment is conducted because populations in West Africa are isolated both biogeographically and behaviourally from breeding populations in other parts of the continent (IUCN, 2003). Additionally, we recommend that future survey efforts focus intensively on populations in Central Africa to facilitate a global assessment of this species.

Strategies for crocodile conservation can include sustainable use and many such programmes for harvest and commercial trade exist in East and southern Africa. We recommend, based on our information on current interest and demand, that any use be focused on the local traditional medicine and religious users. Additionally, we recommend research to understand the traditional medicine and religious market dynamics as a platform for establishing sustainable use programmes.

The successful conservation of crocodiles in Ghana, Côte-d'Ivoire, and West Africa as a whole, will require raised awareness amongst conservation and enforcement personnel. The Crocodile Specialist Group convened the 1st Working Meeting for West African Crocodiles in Parc W, Niger, over November 12-15 2007, with the emphasis on generating a base for future efforts by involving local people throughout West Africa. These activities should be continued, with an emphasis on local involvement and capacitybuilding efforts, without which any conservation initiatives will not be successful in either the short- or long-term.

\section{Acknowledgements}

The success of this project was made possible by our Ghanaian and Ivoirian colleagues and support staff at KNUST in Ghana, and SCNCI, University of CocodyAbidjan, and Akoi Kouadio in Côte-d'Ivoire. We thank Mike Adu-Nsiah of the Ghana Wildlife Division, Ghana, and Col. Kouame Amani Denis of the Wildlife Directorate, Ministry of Water and Forests, Côte-d'Ivoire, for their support and permission to conduct this research. Earlier versions of this article were improved by comments from J. Thorbjarnarson, J. Austin, F. Mazzotti, J.P. Ross and two anonymous reviewers. Protocols for animal and human use were reviewed by the University of Florida IACUC (Protocol \#E423) and IRB (UFIRB \#2006-U-586) committees. Funding was provided by the Wildlife Conservation Society, the Conservation, Food, and Health Foundation, the Columbus Zoological Park Association, Inc. Conservation Fund, IDEA WILD, St Augustine Alligator Farm, and private donations. Many students in Ghana and Côted'Ivoire made this project successful through their enthusiasm to learn about crocodiles and to become better conservation biologists.

\section{References}

Akani, G.C., Luiselli, L., Angelici, F.M. \& Politano, E. (1998) Preliminary data on distribution, habitat and status of crocodiles (Crocodylus niloticus, Crocodylus cataphractus and Osteolaemus tetraspis) in the eastern Niger delta (Nigeria). Bulletin de la Société Herpetologique de France, 87-88, Supplement 3eme et 4eme trimestre, $35-43$.

B ASSETT, T.J. (2005) Card-carrying hunters, rural poverty, and wildlife decline in northern Côte d'Ivoire. The Geographical Journal, 171, 24-35.

BAYLISS, P. (1987) Survey methods and monitoring within crocodile management programmes. In Wildlife Management: Crocodiles and Alligators (eds G.J.W. Webb, S.C. Manolis \& P.J. Whitehead), pp. 157-175. Surrey Beatty and Sons, Sydney, Australia.

Benra, O. (1993) Togo. Crocodile Specialist Group Newsletter, 12, 17. Benra, O. (1994) Crocodiles on the desert's doorstep. Crocodile Specialist Group Newsletter, 13, 4-5. 
Brashares, J.S., Arcese, P., Sam, M.K., Coppolillo, P.B., Sinclair, A.R.E. \& BALMFord, A. (2004) Bushmeat hunting, wildlife decline, and fish supply in West Africa. Science, 306, 1180-1183.

Brown, C.J., Stander, P., Meyer-Rust, R. \& Mayes, S. (2004) Results of a Crocodile Crocodylus niloticus Survey in the River Systems of North-east Namibia During August 2004. CITES Report, CoP13 Inf. 26, Bangkok, Thailand.

Changwe, K. (1996) Crocodile Survey in the Luangwa Valley. Report to Luangwa Integrated Resource Development Project/National Parks and Wildlife Service, Chilanga, Zambia.

Changwe, K. (2004) Hippopotamus and Crocodile Survey in the Luangwa Valley. Report to Zambia Wildlife Authority, Chilanga, Zambia.

Conservation International (2002) Assessment of the Bushmeat Trade During the Annual Closed Season on Hunting in Ghana. Conservation International, Accra, Ghana.

Cowlishaw, G., Mendelson, S. \& Rowcliffe, J.M. (2005a) Evidence for post-depletion sustainability in a mature bushmeat market. Journal of Applied Ecology, 42, 460-468.

Cowlishaw, G., Mendelson, S. \& Rowcliffe, J.M. (2005b) Structure and operation of a bushmeat commodity chain in southwestern Ghana. Conservation Biology, 19, 139-149.

Crookes, D.J., Ankudey, N. \& Milner-Gulland, E.J. (2005) The value of a long-term bushmeat market dataset as an indicator of system dynamics. Environmental Conservation, 32, 333-339.

Damania, R., Milner-Gulland, E.J. \& Crookes, D.J. (2005) A bioeconomic analysis of bushmeat hunting. Proceedings of the Royal Society B, Biological Sciences, 272, 259-266.

DE Smet, K. (1999) Status of the Nile crocodile in the Sahara desert. Hydrobiologia, 391, 81-86.

Dore, M.P.O. (1996) Status of crocodiles in Nigeria. Crocodile Specialist Group Newsletter, 15, 15-16.

Even, E. (1996) Holy crocodiles (Crocodylus niloticus) in Gambia. Lacerta, 54, 56-57.

Fairhead, J. \& Leach, M. (1998) Reframing Deforestation: Global Analyses and Local Realities with Studies in West Africa. Routledge, London, UK.

Games, I. \& Severre, E.L.M. (1999) Tanzanian Crocodile Survey, October 1999. A Report to the Director of Wildlife. Report to the Director of Wildlife, Tanzania.

Ghana Wildiffe Division (1998a) Wildlife Development Plan, Vol. 6: Sustainable Use of Bushmeat. Ghana Wildlife Division Internal Report, Accra, Ghana.

Ghana Wildife Division (1998b) Protected Areas Development Programme, Western Region: Bushmeat Survey. Protected Areas Development Programme, Accra, Ghana.

Ghana Wildlife SociETy (undated) Synthesis Report on Bushmeat Status and Studies Undertaken at the Kyabobo Park in Ghana. Unpublished Report, Ghana Wildlife Society, Accra, Ghana.

Grubb, P. (1998) The Mammals of Ghana, Sierra Leone, and The Gambia. Trendrine, St. Ives, UK.

HaWthorne, W.D. (1996) Holes and the sums of parts in Ghanaian forest: regeneration, scale and sustainable use. In Essays on the Ecology of the Guinea-Congo Rainforest (eds M.D. Swaine, I.J. Alexander \& R. Watling), pp. 75-176. Proceedings of the Royal Society Vol. 104, Edinburgh, UK.

HeKKala, E. (2004) Conservation genetics at the species boundary: case studies from the African and Caribbean crocodiles (Genus: Crocodylus). PhD thesis, Columbia University, New York, USA.

Holbech, L. (2001) A Study on Bushmeat Production and Land Use in the Amokwasuazo Community Resource Management Area, Off-Reserve the Ankasa Resource Reserve, Western Region, Ghana.
Protected Area Development Programme, Wildlife Division of the Forestry Commission, Accra, Ghana.

Holbech, L.H. (undated) Bushmeat Utilization in the Rainforest zone of Western Region, Ghana. Unpublished Report.

Hutton, J.M. \& Woolhouse, M.E.J. (1989) Mark-recapture to assess factors affecting the proportion of a Nile crocodile population seen during spotlight counts at Ngezi, Zimbabwe, and the use of spotlight counts to monitor crocodile abundance. Journal of Applied Ecology, 26, 381-395.

IUCN (2001) 2001 Categories and Criteria (version 3.1). IUCN, Gland, Switzerland [http://www.redlist.org/info/categories_criteria2001.html, accessed 17 September 2008].

IUCN (2003) Guidelines for Application of IUCN Red List Criteria at Regional Levels: Version 3.o. IUCN, Gland, Switzerland and Cambridge, UK [http://intranet.iucn.org/webfiles/doc/ssc/sscwebsite/ Red_List/regionalguidelinesEN.pdf, accessed 18 November 2008].

IUCN (2008) 2008 IUCN Red List of Threatened Species. IUCN, Gland, Switzerland. Http://www.iucnredlist.org [accessed 2 November 2008].

Jachmann, H. (1996) Aerial Survey of the Luangwa Valley Animal Abundance and Population Trends. Luangwa Integrated Resource Development Project, Chipata, Zambia.

Kampamba, G. (2004) Crocodile and Hippopotamus Survey on the Kafue River. Unpublished Report. Zambia Wildlife Authority, Chilanga, Zambia.

Kofron, C.P. (1992) Status and habitats of the three African crocodiles in Liberia. Journal of Tropical Ecology, 8, 265-273.

Kofron, C.P. \& Steiner, C. (1994) Observations on the African dwarf crocodile, Osteolaemus tetraspis. Copeia, 2, 533-535.

Kpera, N. (2003) Notes on crocodiles in Benin. Crocodile Specialist Group Newsletter, 22, 3.

Leslie, A.J. (1997) The ecology and physiology of the Nile crocodile, Crocodylus niloticus, in Lake St Lucia, Kwazulu/Natal, South Africa. PhD thesis, Drexel University, Philadelphia, USA.

Luiselli, L., Politano, E. \& Akani, G.C. (2000) Crocodile distribution in S.E. Nigeria, Part II. Crocodile Specialist Group Newsletter, 19, 4-6.

Mazzotti, F.J., Brandt, L.A., Moler, P. \& Cherkiss, M.S. (2007) American crocodile (Crocodylus acutus) in Florida: recommendations for endangered species recovery and ecosystem restoration. Journal of Herpetology, 41, 122-132.

McAliley, L.R., Willis, R.E., Ray, D.A., White, P.S., Brochu, C.A. \& Densmore, L.D. (2006) Are crocodiles really monophyletic? Evidence for subdivisions from sequence and morphological data. Molecular Phylogenetics and Evolution, 39, $16-32$.

Mendelson, S., Cowlishaw, G. \& Rowcliffe, J.M. (2003) Anatomy of a bushmeat commodity chain in Takoradi, Ghana. Journal of Peasant Studies, 31, 73-100.

Moiser, C.M. \& Barber, A.D. (1994) The crocodile pools of the Western Division, The Gambia. British Herpetological Society Bulletin, 47, 16-22.

Myers, N., Mittermeier, R.A., Mittermeier, C.G., Da Fonseca, G.A.B. \& KENT, J. (2000) Biodiversity hotspots for conservation priorities. Nature, 403, 853-858.

NPWS (National Parks and Wildlife Service) (1993) The National Crocodile Conservation Plan. National Parks and Wildlife Service, Ministry of Tourism, Chilanga, Zambia.

Nyirenda, V. (1997) Hippopotamus and Crocodile in Munyamadzi Game Management Area. Unpublished Report. National Parks and Wildlife Service, Chilanga, Zambia.

Nyirenda, V. (2004) Crocodile Survey of the Zambezi River. Unpublished Report. Zambia Wildlife Authority, Chilanga, Zambia. 
OAtes, J.F. (1999) Myth and Reality in the Rainforest: How Conservation Strategies are Failing in West Africa. University of California Press, Berkeley, USA.

Pooley, A.C. (1980) The status of African crocodiles. In Crocodiles: Proceedings of the Fifth Working Meeting of the Crocodile Specialist Group, Gainesville, Florida, pp. 174-227. IUCN, Gland, Switzerland.

Riley, J. \& Huchzermeyer, F.W. (1999) African dwarf crocodile in the Likouala swamp forest of the Congo basin: habitat, density, and nesting. Copeia, 2, 313-320.

Ross, J.P. (ed.) (1998) Crocodiles. Status Survey and Conservation Action Plan. 2nd edition. Http://www.flmnh.ufl.edu/natsci/ herpetology/act-plan/plan1998a.htm [accessed 4 December 2007].

Rowcliffe, J.M., Milner-Gulland, E.J. \& Cowlishaw, G. (2005) Do bushmeat consumers have other fish to fry? Trends in Ecology \& Evolution, 20, 274-276.

Schmitz, A., Mansfeld, P., Hekkala, E., Shine, T., Nickel, H., Aмато, G. \& Bӧнме, W. (2003) Molecular evidence for species level divergence in African Nile crocodiles Crocodylus niloticus (Laurenti, 1786). Comptes Rendus Palevol, 2, 703-712.

Shine, T., Bohme, W., Nickel, H., Thies, D.F. \& Wilms, T. (2001) Rediscovery of relict populations of the Nile crocodile Crocodylus niloticus in south-eastern Mauritania, with observations on their natural history. Oryx, 35, 260-262.

Simwanza, H. (2004) Aerial Survey of the Mweru-Wantipa Ecosystem. Unpublished Report. Zambia Wildlife Authority, Chilanga, Zambia.

Thompson, W.L. (ed.) (2004) Sampling Rare or Elusive Species: Concepts, Designs, and Techniques for Estimating Population Parameters. Island Press, Washington, DC, USA.

Thorbjarnarson, J., Platt, S.G. \& Saw Tun Khaing, U. (2000) A population survey of the estuarine crocodile in the Ayeyarwady Delta, Myanmar. Oryx, 34, 317-324.

Thorbjarnarson, J. \& Eaton, M. (2004) Preliminary examination of crocodile bushmeat issues in the Republic of Congo and Gabon. In Crocodiles. Proceedings of the 17th Working Meeting of the Crocodile Specialist Group, pp. 236-247, IUCN, Gland, Switzerland.

Toonen, H. (2003) The sacred crocodiles of Bazoule. Crocodile Specialist Group Newsletter, 22, 4.
UNEP-WCMC (2008) UNEP-WCMC Species Database: CITES-Listed Species. UNEP-WCMC, Cambridge, UK. Http://www.cites.org/ eng/resources/species.html [accessed 3 November 2008].

Wait kuwait, W.E. (1985a) Contribution a l'etude des crocodiles en Afrique de l'Ouest. Nature et Faune, 1, 13-29.

W AIT KUWAIT, W.E. (1985b) Investigations of the breeding biology of the West African slender-snouted crocodile Crocodylus cataphractus Cuvier, 1824. Amphibia-Reptilia, 6, 387-399.

Waitkumait, W.E. (1989) Present knowledge on the West African slender-snouted crocodile, Crocodylus cataphractus Cuvier 1824 and the West African dwarf crocodile, Osteolaemus tetraspis, Cope 1861. In Crocodiles: Their Ecology, Management and Conservation (eds P. Hall \& R. Bryant), pp. 259-275. IUCN, Gland, Switzerland.

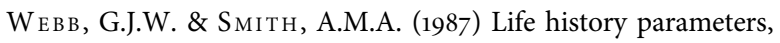
population dynamics and the management of crocodilians. In Wildlife Management: Crocodiles and Alligators (eds G.J.W. Webb, S.C. Manolis \& P.J. Whitehead), pp. 199-210. Surrey Beatty and Sons, Sydney, Australia.

Wilson, R.T. (1978) Notes on the crocodile Crocodylus niloticus in Darfur, Western Sudan. East African Wildlife Journal, 16, 65-67.

Zimbabwe Parks and Wildlife Management Authority (2006) Status of the Wild Crocodile Populations in Zimbabwe. Report to CITES. Http://www.cites.org/common/resources/reports/ranch/ ZW0605.pdf [accessed 3 November 2008].

\section{Biographical sketches}

Matthew Shirley is interested in the conservation of wildlife in developing nations and the challenges that this entails. In his research he utilizes multiple tools including model-based population estimation and molecular ecology and systematics. WILLIAM ODURo has been an advocate for the conservation of Ghanaian, and West African, wildlife throughout his career. He is interested in the international, sustainable trade of reptile species, and how conservation efforts affect local communities. HiLAIRE Y AOKOKORE BEIBRO is principally interested in the conservation of forest birds in the Upper Guinea Forest. He is a founding member of the Society for Nature and Conservation in Côte d'Ivoire. 